\title{
Cheyenne Language
}

National Cancer Institute

\section{Source}

National Cancer Institute. Cheyenne Language. NCI Thesaurus. Code C153886.

A Native American language of the Algonquian language family spoken by the Cheyenne people. 